\title{
Merging Personal and Academic Identities
}

\section{Tamara Harper Shetron Kristie O’Donnell Lussier}

\section{ABOUT THE AUTHORS}

Tamara Harper Shetron is a doctoral candidate in developmental education at Texas State University with a concentration in literacy studies. Her research includes inclusive post-secondary education for students with intellectual and developmental disabilities and active and engaging teaching pedagogy. She is committed to supporting diverse and non-traditional students in higher education and life-long learning settings. Tamara is also an accomplished musician and fine arts consultant. She is actively engaged in the creative arts special interest group sponsored by the American Association of Intellectual and Developmental Disabilities (AAIDD) and she is a the past board president of the Austin based inclusive performing arts company, TILT.

Kristie O'Donnell Lussier is a professor of English and Integrated Reading and Writing at Collin College. She is a graduate of Texas State University where she earned a Ph.D. in Developmental Education- Literacy and an M.A. in Rhetoric and Composition. Kristie's professional interests lie in literacy education, academic literacies, postsecondary educational transitions, and the role of language in personal and educational development. Kristie has presented and published on college student literacy development, teacher education in international and multilingual settings, student identity development, humanizing pedagogy, and language and literacy development in international settings.

$\mathrm{n}$ this article, we describe rationales and processes of using a tableau theater model for student engagement in a developmental education literacy course. Tableau theater is an instructional technique in which students physically reenact moments in texts they read. Asher's (1969) total physical response (TPR), and constructivist and theories of embodied literacies (Cope \& Kalantzis, 2009; New London Group, 1996) informed the development of this technique. Repeated use of this instructional model in a variety of class contexts and with different texts and instructors demonstrated the value of using classroom time to allow students to engage physically with the text and create their own meaning, thus putting them in control of building their own academic identities.

As literacy instructors, we set out to engage students in a meaningful understanding of texts by creating an opportunity for students to actually step into the situation. According to Asher (1969), when students physically engage with material that they are learning, the combination of both physical and mental interaction with it engages both hemispheres of the brain. Asher's work demonstrates that physical response to language naturally occurs before a verbal response. Butterwick and Selman (2012) focused on the power that theater processes have due to the inclusivity of all our senses. More specifically, Dolan (2001) argued for the use of theater in the public sphere as a means for deep engagement with complex modern issues from multiple perspectives.

From our perspectives as teachers of developmental literacy courses, we understand that part of the developmental literacy process is meant to help students form scholarly identities and relate themselves to the academic world in meaningful and personal ways. The processing of stepping into the textual experience allows students to embody the literacies they are experiencing and to take personal control of their learning.

The process of academic community building is a process of merging identities between the existing home community and the new academic community (New London Group, 1996; Tapp, 2014). By embodying the situation physically and having the chance to talk through the situation and the text with their peers and instructor and to have time to reflect on their personal journey through the tableau exercise, students engage many aspects of their literacy learning. Indeed, students express that making meaning through tableau sheds new light on reading and writing transactions, personal expression, and agency. In our experiences, students make a far more engaged and dynamic response to their literature when they connect through tableau.

\section{The process of academic} community building is a process of merging identities between the existing home community and the new academic community. 
As scholars, we set out to answer the question, "how do students respond to and engage in tableau theater?" Our question is framed by social constructivism (Vygotsky, 1978) and builds on Sheehy's (2004) notion that "engagement is a chief concern of literacy research" (p. 93). In this case, students individually interact with a text to construct their own interpretations based upon their past experiences, the text, and their participation in the textual activity through tableau. By studying the student-produced work, we have been able to identify several themes that answer this question; we will highlight two of these. First, students achieve an active subjective engagement with texts. For example, in one tableau iteration, several students changed the outcomes of the role in which they were positioned and reasoned through their thought processes through writing. Second, students were better able to connect what they were learning to experiences in their own lives. For example, in their reflections, some students were able to compare and contrast analogous experiences from their lives. Furthermore, some students began this critical comparison with little direct prompting to do so.

With its inclusivity of all the senses (Butterwick \& Selman, 2012), tableau provides the opportunity for students to take on the roles of others, allowing for a deeper exploration of positionality as well as multiple and sometimes contradictory responses to the same text. This provides an antithesis to the banking method of education in which students are directed in their thoughts and interpretation of a text (Freire, 1993) by providing a rich classroom instructional pedagogy whereby students can develop their own academic identities bridging their own prior experiences and responses to classroom activities.

\section{References}

Asher, J. J. (1969). The total physical response to second language learning. The Modern Language Journal, 53(1), 3-17.

Butterwick, S., \& Selman, J. (2012). Embodied knowledge and decolonization: Walking with theater's powerful and risky pedagogy. New Directions for Adult and Continuing Education, 2012(134), 61-69.

Cope, B., \& Kalantzis, M. (2009). "Multiliteracies": New literacies, new learning. Pedagogies: An International Journal, 4(3), 164-195.

Dolan, J. (2001). Rehearsing democracy: Advocacy, public intellectuals, and civic engagement in theatre and performance studies. Theatre Topics, 11(1), 1-17.

Freire, P. (1993). Pedagogy of the oppressed. New York, NY: Bloomsbury.

New London Group. (1996). A pedagogy of multiliteracies: Designing social futures. Harvard Educational Review, 66, 60-92.

Sheehy, M. (2004). Between a thick and a thin place: Changing literacy practices. Spatializing Literacy Research and Practice, 15, 91-114.

Tapp, J. (2014). "I actually listened, I'm proud of myself," the effects of a participatory pedagogy on students' constructions of academic identities. Teaching in Higher Education, 19(4), 323-335.

Vygotsky, L. S. (1978). Mind in society: The development of higher psychological processes. Cambridge, MA: Harvard University. 